Article

\title{
Drivers for Sustainable Business Models in Start-Ups: Multiple Case Studies
}

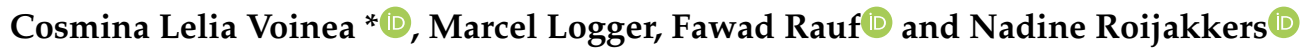 \\ Faculty of Management, Science and Technology, Open University of the Netherlands, 6419 AT Heerlen, \\ The Netherlands; marcel.logger@holland-innovative.nl (M.L.); fawadrauf1989@yahoo.com (F.R.); \\ nadine.roijakkers@ou.nl (N.R.) \\ * Correspondence: cosmina.voinea@ou.nl
}

Received: 8 October 2019; Accepted: 21 November 2019; Published: 4 December 2019

check for updates

\begin{abstract}
Mechanisms that large organizations employ to facilitate corporate social responsibility (CSR) engagement simply do not apply to start-ups due to distinct differences. The purpose of this study was to gain insight into how start-ups strive for sustainability in their business models by investigating internal and external drivers related to organizational processes, managerial characteristics, and stakeholder expectations. We explored key factors such as decision-making regarding CSR engagement, business values about sustainability, entrepreneurial orientation, and the relevance of the CSR theater (philanthropic orientation, disruptive innovation, or transforming the ecosystem). Multiple case studies and interview data elucidated how start-ups engage with their community and stakeholders to determine the best approach to sustainability demands, how start-ups embed sustainability practices within their business models, and how these practices match with the entrepreneurs' personalities. On the basis of our case studies and data analysis, we propose that the decision to engage in CSR is treated as an investment decision. The business values of a start-up determine its CSR engagement. The philanthropic drive of a start-up determines its CSR initiatives, which are then in line with the field the start-up is operating in. Entrepreneurs' willingness to adopt CSR practices is determined by their personalities and organizational expertise and experiences. CSR engagement within the business models of start-ups is based on a combination of financial and social capital, while financial benefits act as a continuous motivator for CSR engagement from inception.
\end{abstract}

Keywords: start-ups; sustainability; CSR; sustainable business models; entrepreneurial orientation; stakeholders

\section{Introduction}

Start-ups needs to find a proper balance between entrepreneurial ideas and CSR endeavors, meaning that a start-up needs to adopt those CSR practices that are relevant to its business and are feasible in relation to the organization's profitability [1,2] and competitiveness. However, much of today's developed and available CSR literature focuses on the implementation, development, and understanding of CSR in large enterprises and small and medium enterprises (SMEs) [1,3-10]. There is far less attention dedicated to how new business start-ups have established, adapted, or implemented social responsibility to improve the welfare of their stakeholders $[9,11]$.

Business start-ups comprise different characteristics compared to other types of firms [9], which becomes evident in a number of business elements. A start-up is an entrepreneurial venture in its early stages of operations that is typically aimed at resolving a real-life issue with an innovative product or service. These ventures are typically small in nature, new, and funded either by a founding entrepreneur or by a group of investors who believe in the entrepreneurial concept. A start-up lacks real stakeholders (compared to more experienced established firms), which forces the start-up 
entrepreneur to think of potential and future ones [9]. In some cases, even newly established firms are not as responsible for their surrounding environments and societies as larger businesses are, because they often fall below or outside the requirements of specific national regulations and as such avoid their responsibilities to several stakeholders [12,13]. Moreover, newly established enterprises lack formal tools, such as social and environmental reports, as these disclosures require the investment of time, financial resources, and competencies with respect to implementing new organizational routines $[14,15]$. The organizational structure and managerial experience within a start-up are also different from those within a large firm. Where a large firm has a formal bureaucratic administration process and professional management, the start-up typically has an informal and flexible organizational structure [16,17]. Another difference is the size of the firm. Large firms have the resources to spend time to create a CSR approach to serve their stakeholders' needs and demands, whereas start-ups are generally stretched for time and resources [11], constantly balancing between adding value to their product or service and serving stakeholders' needs.

The current methods for embedding CSR in large firms and SMEs have their limitations for application in start-ups [9] and do not necessarily apply to small firms because of their distinctly different characteristics [3,17]. Given the liability of newness that characterizes start-ups, it is paramount to investigate how these firms manage stakeholder expectations given limited resources [18,19], knowledge, and social capital $[20,21]$. While relatively few studies have investigated how start-ups deal with CSR demands in their business $[9,11]$ the current research fills this gap by investigating the drivers of CSR into the business model from inception. The essence of a business model is defining how the company creates value for customers, entices customers to pay for this value, and translates these payments into profit [22]. A business model is a means to compete [23]. To incorporate CSR into the business model, an extension of the Canvas business model is necessary. This extension is represented by building blocks that show two outcomes: the social and environmental costs of a business model and the social and environmental benefits of a business model. This would be applicable, for example, to social start-ups [24]. It is therefore important that more attention be paid to mechanisms that enable start-ups to facilitate CSR engagement. Therefore, the objective of this research is to further explain CSR engagement in the business model of start-ups by investigating how start-ups have implemented and applied CSR in their business models and elucidating what are the internal and external drivers for sustainable business models in start-ups.

This study contributes to social capital theory by redirecting the attention of CSR researchers from a traditional viewpoint of CSR engagement based on stakeholder theory in larger firms. The existing theory lacks research findings that explain the CSR engagement of start-ups. Ref [25] have argued that start-ups should use the theory of social capital to understand CSR engagement. Hence, this study adds more knowledge by examining how start-ups engage in CSR and what motivations drive such firms to engage in CSR activities. Practically, this study can prove to be significant for entrepreneurs who are starting up a new business endeavor and contemplating how they should deal with social expectations from their stakeholders. This study could be used to establish specific strategies and instruments, which may enhance a start-up's competitive advantage and improve the welfare of stakeholders.

\section{CSR Engagement}

Organizations are embedded in complex networks of natural and social relationships, such as shareholders, managers, employees, customers, local populations, and networks, and they embrace multiple actors from the public and voluntary sectors, all of which fall within the stakeholder category as any group or individual who can affect or is affected by the achievement of an organization's objectives. This validates the application of stakeholder theory, which is largely applied to determine the relationship between large firms and CSR engagement [26]. However, several researchers have suggested that stakeholder theory does not necessarily explain the CSR relationship in start-ups, since they did not find it possible to generalize their findings [17]. Start-ups are, in general, actively managed by their owners/entrepreneurs, highly personalized, and largely local in their area of operation [12]. 
The main reason why the application of stakeholder theory is difficult in a start-up is the lack of real stakeholders, which forces the entrepreneur to think of potential and future ones [9]. This does not mean that a start-up must eliminate stakeholder theory from consideration; on the contrary, a start-up must hear stakeholders' needs and expectations. Refs $[8,25]$ have proposed the theory of social capital to explore the CSR-SME relationship, which refers to individual relationship issues such as trust, norms, and networks. In fact, SMEs and start-ups are social entities that revolve around personal relationships [27].

Social capital accrues through engagement, networking within sectors, networking across sectors, volunteerism, and donating to $[12,13,26,28]$. Social capital theory stipulates that reputation, trust, and legitimacy become key intangible stock for organizations (and the basis for long-term results) and suggests that the relationship with stakeholders is close, unique, highly personalized, and often on a one-on-one basis [8]. It supports the view that CSR activities carried out within start-ups are scarcely systematic, are not structured into formalized strategic processes, and have low visibility outside the company. Ref [8] defines this approach to CSR as "sunken" CSR: it is there, but it is less formal and most of the time not communicated or shared with the outside world. Ref [8] promotes, therefore, a combination of both the theory of a stakeholder's perspective and the theory of social capital perspective as a basis for CSR research in the context of SMEs. Through the theory of stakeholders, a start-up exists to create value for multiple stakeholders, with whom the firm has a stronger relationship than do more experienced/already established firms, and these stakeholders are often embedded within social capital. Being embedded in local communities in which the firm operates serves as a basis for long-term performance because start-ups are more willing to gain intangible assets than are large firms. The resources and competencies used by start-up firms are often embedded within their social capital. Therefore, we assumed that CSR engagement within start-ups is based on a combination of financial and social capital.

\section{The Business Case for CSR}

Evidence shows that stakeholders prefer to associate with firms that are committed to socially responsible behaviors $[29,30]$ because the presumption is that firms that actively support CSR are more reliable, and therefore their products are of higher quality [31]. Ref [7] refers to a number of benefits for companies adopting CSR strategies, which could involve dimensions such as cost savings, enhanced staff loyalty, improved government relations, innovation and learning, enhanced reputation, and consumer response.

The reputation and attractiveness of a company are not measured in financial measures but in whether they behave ethically and are socially active and involved in the surrounding society. Venture capitalists, for instance, are looking to invest in sustainable businesses that are economically viable but also contribute positively at a societal and environmental level [32]. Venture capitalists invest in businesses, not in nonprofit organizations, in return for shares in the business. Environmental and societal success needs to be significant, but financial success needs to be competitive as well. Thus, if a venture adds a positive societal and environmental impact, but lacks profit potential, it will not fit the investment objectives of venture capitalists [32]. Therefore, the concept is that companies with better CSR plans obtain far better gains in business, possess many more faithful customers, and are generally much more successful. Corporations are more profitable if they maintain mutually beneficial relations based on trust with their suppliers, creditors, and customers, as well as with local communities and governments [13,32]. However, is that really the case? Ref [31] argues that although firms providing CSR will have higher costs than firms not providing CSR, they will each have the same rate of profit. They predict that there will generally be a neutral relationship between CSR activity and firm financial performance. Ref [32] makes reference to ventures having a clear business case for CSR, but not necessarily being sustainable, which would give customers clear benefits. CSR directly affects the very people who invest in the company, therefore creating a cycle of benefit for both the organizations and the community [4] which requires investing corporate resources for a payoff that is 
both distant and uncertain [33]. It is more beneficial to a firm if their social and economic goals are not inherently conflicting, but rather integrally connected [4,34].

Some managers eschew attempts to satisfy the demand for CSR because they believe that such efforts are inconsistent with profit maximization and the interests of shareholders, whom they perceive to be the most important stakeholders. Ref [31] outlines a supply and demand model of corporate social responsibility to determine the appropriate level of CSR investment, which implies that there is some optimal level of CSR attributes for firms to provide, depending on the demand for these characteristics and the costs of generating them (i.e., a cost-benefit analysis). The decision to engage in CSR at par relies on shareholder value maximization. However, some studies have suggested that this and satisfying certain stakeholders' interests are not mutually exclusive. Ref [35] seconds this potential compatibility through enlightened value maximization, whereby the firm's objective is specified as long-term value maximization or value seeking. Besides, this objective shapes the criteria for the requisite tradeoff between the stakeholders' interests [36]. Managers should treat decisions regarding CSR precisely as they treat all investment decisions. For start-ups, the bottom line of short-term economic survival is more pressing. Start-ups tend to be more vulnerable to economic losses and will thus be more dependent on the direct economic benefits of CSR-oriented strategies [7], which is even more pressing for start-ups. Thus, we assumed that the decision to engage in CSR is treated as an investment decision.

\section{CSR Theater}

The company owner, the start-up entrepreneur, is a key driver in engaging in CSR, as the entrepreneur's vision and commitment to contributing to the community and society of which they are a part determine the "CSR theater" classification a company is willing to work in [33]. The three CSR theaters discussed in this section are "philanthropic"-oriented, oriented toward "reengineering the value chain", and oriented toward "transforming the ecosystem". The research in this section suggested that the initial business choice, e.g., "What will be the true intentions of our business?", and a start-up's social or environmental purpose logically determine CSR engagement.

The philanthropic-oriented theater is driven by the entrepreneur's personal, social, and environmental priorities, which are reflected in a company's nonprofit business values and address social and environmental topics. Philanthropy initiatives could be in the form of direct funding to nonprofit and community service organizations and employee community service projects or could include in-kind donations of products and services to nonprofits and underserved populations [33]. The entrepreneur engages in CSR because it is a good thing to do, as it expresses the beliefs of the founder, but there should be a link between strategic intent and business priorities.

A second theater seeks to co-create economic and social values, focusing on increasing business opportunities and profitability while also creating social and environmental benefits: this is called reengineering the value chain [33] (where value is co-created for both internal and external stakeholders). This theater is characterized by incremental and self-interested change primarily focused on increasing profits. CSR engagements in this theater seek to reengineer a company's entire value chain by improving operational effectiveness throughout the value chain, be it upstream in the supply chain or downstream in the distribution chain, including natural resource extraction and sourcing, manufacturing, shipping, and product delivery. Companies in the second theater have much more potential for social and environmental benefits than companies doing business in the first theater, since CSR practices are implemented throughout the company's value chain and emerge from the company's core competencies [26]. In addition, in this theater, a company may engage in charitable giving not by choice, but because of societal pressures.

The third theater is characterized by creating societal value through significantly addressing a critical social or environmental need that is within reach of a business but that may not return immediate business profits: this is called transforming the ecosystem [33]. The company's actions in this theater emerge typically from a disruptive innovation that forces the company to fundamentally 
change its business model and develop new skills and strategies. The company creates a radically new ecosystem solution that may be outside its business interests and that is fundamentally disruptive to the existing value chain, which requires risk-taking and a focus on long-range rather than short-term economic gains.

It is not said that a start-up needs to accommodate all three CSR theaters: this depends on the origins of a particular CSR initiative. However, working in any of the three CSR theaters entails strategic implications that affect choices between a wide range of CSR initiatives, depending on the opportunities a company has to have a social or environmental impact. Ref [33] surveyed CSR managers and identified CSR initiatives. From these CSR initiatives, roughly $40 \%$ fit in theater 1 (i.e., the initiatives were philanthropic-oriented), $40 \%$ fit in theater 2 (i.e., the initiatives focused on reengineering the value chain), and $20 \%$ fit under theater 3 (i.e., the CSR initiatives focused on transforming the ecosystem) (with different motivations and expected benefits that their companies hoped to derive). From the above, one cannot conclude that there is a specific theater/orientation of CSR initiatives that takes precedence over another with respect to CSR engagement. This led us to assume that the business values of a start-up determine its CSR engagement.

\section{Entrepreneurial Orientation}

Various combinations of individual and organizational factors define how entrepreneurship occurs as it does: this is called "entrepreneurial orientation" and it puts key entrepreneurial processes into five dimensions (autonomy, innovativeness, risk-taking, proactiveness, and competitive aggressiveness). Autonomy refers to the ability and will to be self-directed in the pursuit of opportunities. Innovativeness means to engage in and support new ideas, novelty, experimentation, and creative processes that may result in new products, services, or technological processes. Risk-taking is about venturing into the unknown, which primarily involves committing a relatively large portion of assets. Proactiveness means having a forward-looking perspective on the future needs of markets and stakeholders, and competitive aggressiveness refers to a new entrant needing to compete with an existing rival [37]. Designing a business model is an incremental and iterative process $[23,38]$ in which learning and adaptation contribute to success. The start-up of a company is complex and demanding, and the search for a flexible and suitable business model is a necessity for every start-up. Refs $[24,38]$ argue that continuous experimentation contributes to gaining knowledge and new ways to give substance to a business. This application is essential for a start-up's learning cycle for four reasons. First, it is an exercise in constant reflection for the entrepreneur. Secondly, it provides insight into the coherence between various components and stakeholders, which can be the starting point for new business ideas. Third, it forces the entrepreneur to look at the business in a holistic way. Finally, graphic representation contributes to creativity and innovation in relation to business.

The more experienced an entrepreneur is, and the more an entrepreneur exhibits expertise, the more he or she favors thriving in the five dimensions (autonomy, innovativeness, risk-taking, proactiveness, and competitive aggressiveness) [39] and acting entrepreneurially to engage in CSR. This means that the manner in which a firm adopts and engages in CSR is related to the entrepreneur's experience and expertise, which influence the CSR engagement of the start-up.

\section{Methodology}

\subsection{Research Design}

The objective of this research was to explain the drivers of CSR in the business models of start-ups. Start-ups could consciously use CSR elements to combine impacts on society and competitive advantage [37]. Start-ups often have to do with a high degree of uncertainty and many risks [38]. Understanding the effects of CSR on the business model could make the business model more robust [37]. The methodological perspective most suited to this research objective, and the one adopted for this study, was exploratory multiple-case-study research. The choice to do exploratory case study 
research was made for the reasons given by several authors that have used such an approach: holistic and meaningful characteristics of real-life events, such as organizational and managerial processes [40]; insights into a topic of interest [41]; qualitative research that studies meanings and the relationships between them [42]; relevant behaviors that cannot be manipulated [43]; and boundaries between phenomena and contexts that are not clearly evident [40]. Evidence from multiple cases is considered more compelling and is regarded as being more robust [44]. Furthermore, case studies are suitable for studies aiming to sketch an overall picture of a phenomenon in its context [45].

\subsection{Data Collection and Method of Analysis}

For the multiple-case-study, a select sample of cases was used. The firm had to meet the start-up criterion (the company brings products/services to the market; the business must clearly show that the start-up is aimed at creating social impact; and the business started a maximum of seven years ago). However, the date of incorporation also played a role because the interviews focused on developments from the founding date. Furthermore, spreading the foundation data provided insight into the focus of the initiators during the first years and afterwards. All start-ups participating in this study are based in the Netherlands and act in an international context. Start-up company NL1, founded in 2016, operates in the medical sector and develops a device that helps the specialist better diagnose a specific medical condition and thus improve the efficiency of treatment together, leading to a higher probability of healing. This device makes the diagnosis process less of a burden for the patient compared to the current way of practice. Start-up company NL2, founded in 2014, operates in the high-tech sector and develops a diagnostic device that is able to analyze the composition of substances more accurately: it is quick, free of errors, and nondestructive. Start-up company NL3, founded 2016, operates in the medical sector developing a product that enables the better monitoring of babies, resulting in less stress and inconvenience for both parents and children. Start-up company NL4, founded in 2014, operates in the medical sector. This company has developed a harvesting method that extracts natural high-quality content substances from plants used to manufacture medicines more cheaply and efficiently, and it is nondestructive for the plant. Start-up company NL5, founded in 2012, operates in utility construction and has developed solar facades, making a positive contribution to the energy transition from fossil fuels to sustainable and clean energy During the remainder of this study, the start-ups will be identified according to the codes described above.

According to ref [45], the lifelike nature of a research situation and data collection are typical for qualitative research. For research into the use of CSR as a core competency, it must be discovered what knowledge and expertise the entrepreneurs have incorporated into their business models. Personal feelings with regard to social involvement also play a role, therefore interviews are best suited [46]. For this research, a semistructured set-up was chosen in order to, on the one hand, receive answers that were in line with operationalization and, on the other hand, give room for the personal input of the entrepreneur. Thus, the researchers used a semistructured interview approach containing predetermined questions (see Appendix A) to increase the completeness of the data and make data collection more systematic for each participant to anticipate and address potential gaps in the process and to maintain the conversational and situational nature of the interviews [44].

The researchers chose a deductive approach that involved (1) deciding on the unit size of analysis; (2) developing a structured analysis matrix (categories) for coding the data according to predetermined criteria to match a proposition category of data; and (3) analyzing comparisons between the companies involved in the study with respect to the propositions. Refs [47,48] describe one of the most applicable trustworthiness checks in qualitative research: stakeholder checks. Stakeholder checks enhance the credibility of findings by allowing participants to comment on or assess the research findings, interpretations, and conclusions. The researchers ensured stakeholder checks by providing interviewees with full access to the summarized results of the respondents. 


\subsection{Operationalization}

\subsubsection{CSR Engagement}

CSR engagement is indicated by CSR practices a start-up has engaged in, such as environmental efforts, benefiting charities, engaging in local community programs, treating employees fairly and ethically, attending volunteer events, embracing safety and health, tending to the workplace environment, and interacting with customers and suppliers: these can be categorized into the four domains of Carrol's hierarchy of CSR (i.e., economic, legal, ethical, and discretionary responsibility) by using the criteria for each category, as embodied in ref [49]. Stakeholder and social capital theory provide items to analyze the foundation for CSR engagement: this was operationalized based [50], where the following dimensions were investigated: external impact, external drivers, the organization-stakeholders-society relationship, profit, shareholder value, investor relations, the planet, neighborhoods, people, safety and health, work ethics, consumers, and suppliers. Accordingly, a detailed operationalization of the concepts is presented in Figure 1.

\begin{tabular}{|c|c|c|c|}
\hline Variable & Dimensions & Operationalization / Indicators & Source \\
\hline \multirow[t]{37}{*}{ CSR Engagement (Stakeholder vs social theory) } & \multirow{5}{*}{ External Drivers behind CS } & Enforced by authorities & van Marrewijk and Werre (2002) \\
\hline & & Pressure from markets & van Marrewijk and Werre (2002) \\
\hline & & Requests from employees & van Marrewijk and Werre (2002) \\
\hline & & Requests from other stakeholders & van Marrewijk and Werre (2002) \\
\hline & & As a consequence of organizational actions & van Marrewijk and Werre (2002) \\
\hline & \multirow{5}{*}{$\begin{array}{l}\text { Organizational Stakeholder - } \\
\text { Society relationship }\end{array}$} & Act in unsocial and unsustainable way & van Marrewijk and Werre (2002) \\
\hline & & Responsibility of the state & van Marrewijk and Werre (2002) \\
\hline & & Shareholders come first & van Marrewijk and Werre (2002) \\
\hline & & Dialogue with stakeholders / society & van Marrewijk and Werre (2002) \\
\hline & & Relevant stakeholders interest taken into account & van Marrewijk and Werre (2002) \\
\hline & \multirow{4}{*}{ Shareholder Value } & Keep owners satisfied & van Marrewijk and Werre (2002) \\
\hline & & Maximising shareholders value is key & van Marrewijk and Werre (2002) \\
\hline & & $\begin{array}{l}\text { Balancing Shareholders value with interest of } \\
\text { other legitimate stakeholders }\end{array}$ & van Marrewijk and Werre (2002) \\
\hline & & $\begin{array}{l}\text { Increase of stakeholders values furthers } \\
\text { shareholders returns as well }\end{array}$ & van Marrewijk and Werre (2002) \\
\hline & \multirow{3}{*}{ Investor relations } & Proactive managing stakeholder relations & van Marrewijk and Werre (2002) \\
\hline & & Exchange of social and environmental information & van Marrewijk and Werre (2002) \\
\hline & & Full info on CSR performance & van Marrewijk and Werre (2002) \\
\hline & \multirow{3}{*}{ Neighbourhood } & Compliance with relevant regulations & van Marrewijk and Werre (2002) \\
\hline & & Supporting neighbourhood development & van Marrewijk and Werre (2002) \\
\hline & & Together win approach & van Marrewijk and Werre (2002) \\
\hline & \multirow{5}{*}{ Safety \& Health } & Respond to acute problems & van Marrewijk and Werre (2002) \\
\hline & & Compliance with regulations & van Marrewijk and Werre (2002) \\
\hline & & Cost-benefit appraisal & van Marrewijk and Werre (2002) \\
\hline & & Management system in place & van Marrewijk and Werre (2002) \\
\hline & & Pro-active policy & van Marrewijk and Werre (2002) \\
\hline & \multirow{4}{*}{ Work Ethics } & Pragmatism & van Marrewijk and Werre (2002) \\
\hline & & Ethical imperialism - act abroad as when at home & van Marrewijk and Werre (2002) \\
\hline & & Situational relativism & van Marrewijk and Werre (2002) \\
\hline & & Proactive policies defined & van Marrewijk and Werre (2002) \\
\hline & \multirow{4}{*}{ Consumers } & Market oriented, but push & van Marrewijk and Werre (2002) \\
\hline & & $\begin{array}{l}\begin{array}{l}\text { Discovery of the human being behind the } \\
\text { customer }\end{array} \\
\end{array}$ & van Marrewijk and Werre (2002) \\
\hline & & Customer oriented (co-creation) & van Marrewijk and Werre (2002) \\
\hline & & Integrated production - consumer systems & van Marrewijk and Werre (2002) \\
\hline & \multirow{4}{*}{ Suppliers } & Sub-contracting based on cost & van Marrewijk and Werre (2002) \\
\hline & & Co-makership & van Marrewijk and Werre (2002) \\
\hline & & Strategic partnership & van Marrewijk and Werre (2002) \\
\hline & & Integrated supply chains & |van Marrewijk and Werre (2002) \\
\hline
\end{tabular}

Figure 1. Operationalization of CSR engagement: stakeholder/shareholder theory.

\subsubsection{Investment Decision}

The operationalization of the investment decision was based on a study by ref [31]. In this study, it was argued that in order for firms to engage in CSR, those firms must devote resources to realizing CSR initiatives. According to ref [31], resources are assets, capabilities, organizational processes, firm attributes, information, knowledge, etc., that are controlled by the firm. Firms use these resources to generate output, which results in higher costs. Firms must do cost-benefit analyses to make critical 
decisions regarding the optimal use of input to generate CSR initiatives, depending on the demand for CSR initiatives and the costs associated with generating them [31]. This variable was measured through probing questions to the start-up owner about resources being devoted to realizing CSR initiatives and whether these were subjected to a cost-benefit analysis. The items in Figure 2 below were used to operationalize "investment decision".

\begin{tabular}{|c|c|c|c|}
\hline Variable & Dimensions & Operationalization / Indicators & Source \\
\hline \multirow[t]{12}{*}{ Business Case CS (investment decision) } & \multirow{12}{*}{ Criteria for Decision making } & Shortest 'pay out period' & van Marrewijk and Werre (2002) \\
\hline & & Highest 'expected profit' & van Marrewijk and Werre (2002) \\
\hline & & Consensus with relevant stakeholders & van Marrewijk and Werre (2002) \\
\hline & & $\begin{array}{l}\text { Taking into account all available expertise and } \\
\text { considerations }\end{array}$ & van Marrewijk and Werre (2002) \\
\hline & & Long term view perspective & van Marrewijk and Werre (2002) \\
\hline & & Cost-benefits analysis & McWilliams and Siegel (2001) \\
\hline & & Use of analytical tools to make decisions & McWilliams and Siegel (2001) \\
\hline & & Mechanisms / Framework to make decisions & McWilliams and Siegel (2001) \\
\hline & & $\begin{array}{l}\text { Resources allocated (capabilities, information, } \\
\text { knowledge, firm attributes) }\end{array}$ & McWilliams and Siegel (2001) \\
\hline & & Conflict with Profitability & Crane et al. (2011) \\
\hline & & Benefit for organization and community & Deigh (2016) \\
\hline & & $\begin{array}{l}\text { Social and economic goals are integrally } \\
\text { connected }\end{array}$ & Deigh (2016) \\
\hline
\end{tabular}

Figure 2. Operationalization of "investment decision".

\subsubsection{Business Values}

Ref [33] provided indicators for the "philanthropic" theater, the "reengineering the value chain" theater, and the "transforming the ecosystem" theater. Ref [33] gave suggestions which focused on internal drivers and motivations behind CSR. On the basis of the answers to the questions related to principle dimensions, the researchers could investigate the relationship between business values and CSR engagement. Figure 3 presents the operationalization for business values.

\begin{tabular}{|c|c|c|c|}
\hline Variable & Dimensions & Operationalization / Indicators & Source \\
\hline \multirow[t]{19}{*}{ Business Values (CSR Theatre) } & \multirow{7}{*}{ CS Ambition } & Providing welfare to society & van Marrewijk and Werre (2002) \\
\hline & & Taking into account laws and regulations & van Marrewijk and Werre (2002) \\
\hline & & Integration in business & van Marrewijk and Werre (2002) \\
\hline & & Financial result driven & van Marrewijk and Werre (2002) \\
\hline & & Beyond profit considerations & van Marrewijk and Werre (2002) \\
\hline & & Synergistic approach & van Marrewijk and Werre (2002) \\
\hline & & Contributing now and in the future & van Marrewijk and Werre (2002) \\
\hline & \multirow{7}{*}{$\begin{array}{l}\text { Internal drivers / motivation } \\
\text { behind CS }\end{array}$} & Moral duty & van Marrewijk and Werre (2002) \\
\hline & & Personal and Financial Success & van Marrewijk and Werre (2002) \\
\hline & & $\begin{array}{l}\text { Sustainability, social and environmental aspects } \\
\text { are important }\end{array}$ & van Marrewijk and Werre (2002) \\
\hline & & Universal responsibility towards all other beings & van Marrewijk and Werre (2002) \\
\hline & & $\begin{array}{l}\text { Social Value created at the cost of economic value } \\
\text { creation }\end{array}$ & Rangan et al. (2012) \\
\hline & & $\begin{array}{l}\text { Economic/ Social / environmental value designed } \\
\text { to be co-created }\end{array}$ & Rangan et al. (2012) \\
\hline & & $\begin{array}{l}\text { Economic, environmental and social value } \\
\text { converge, but only in the long run }\end{array}$ & Rangan et al. (2012) \\
\hline & \multirow{5}{*}{ Environmental Management } & Environments are exploited for short term gain & van Marrewijk and Werre (2002) \\
\hline & & Compliance oriented & van Marrewijk and Werre (2002) \\
\hline & & CSR measures must improve profit & van Marrewijk and Werre (2002) \\
\hline & & Minimize impact on environment & van Marrewijk and Werre (2002) \\
\hline & & Pursuit to reach zero impact on environment & van Marrewijk and Werre (2002) \\
\hline
\end{tabular}

Figure 3. Operationalization of "business values".

\subsubsection{Entrepreneurial Orientation}

Entrepreneurial orientation was captured by asking the start-up owners about their experience and expertise. An overview of this operationalization can be found in Figure 4. 


\begin{tabular}{|l|l|l|l|}
\hline Variable & Dimensions & Operationalization / Indicators & Source \\
\hline Entrepreneurial orientation & & $\begin{array}{l}\text { Technical expertise and industry knowledge } \\
\text { inhibited by Entrepreneur }\end{array}$ & Lumpkin and Dess (1996) \\
\cline { 3 - 5 } & & CSR expertise inhibited by Entrepreneur & Lumpkin and Dess (1996) \\
\hline
\end{tabular}

Figure 4. Operationalization of "entrepreneurial orientation".

\section{Results}

\subsection{Proposition 1: CSR Engagement}

The case and interview data showed that all cases within this study pursue shared social and/or environmental objectives and recognize that economic objectives are equally important and maybe even more important, as they enable good for society. All start-ups commented that they feel the first line of pressure from their shareholders and manage their needs, which is related to turnover and profit. All start-ups in this study consider whether CSR fits with their businesses and whether it contributes to their financial position and business proposition. That is, start-ups involve CSR strategies with an important impact on the bottom line, reflecting an attempt to secure a license to operate in the communities they operate in.

At the same time, all start-ups in this study reported a deeply rooted drive to do good for society, which is, as one start-up commented "in our hearts and minds, with personal motives". This stems from the individual behavior of the entrepreneur, since they voluntary act the way they do and have a natural aptitude to behave responsibly.

Not all start-ups want to be viewed as a company where you can just buy a product, but want to be associated with doing good for the community in different ways. Two out of the five start-ups, for instance, are deeply concerned about unemployment in their region and want to become sustainable companies where people have a job. Another start-up wants to help law enforcement to track people who perform illegal activities by making their technology available without costs attached to detect drugs, antibiotics, and doping. Another one is contributing to improving babies' lives by developing a product that results in less stress and inconvenience and wants to set up a foundation to help babies in developing countries. Alternatively, one start-up wants to contribute to decreasing medicinal costs by harvesting plant substrates in a more efficient way. In addition, one start-up wants to make a positive contribution to the energy transition from current fossil fuels to sustainable and clean energy. They all do this by engaging within networks of mutual acquaintance and recognition to pursue shared objectives.

Regarding documenting CSR strategy, only one out of the five cases in this study had documented vision, personal drive, or thoughts in an official document or statement of any kind. That start-up documented future thoughts about setting up a foundation in an investment memorandum, which was signed by all concerned stakeholders. This is in line with ref [12]'s research, which argued that informal CSR strategies prevail among micro-, small-, and medium-sized enterprises, which has an important impact on the bottom line. Start-ups have a scarce need for formal management systems, although there are no indications that there is an unwillingness to go for processes that are more formal.

Figure 5 shows the results after coding the data according to the coding framework.

To accomplish a good way of doing business and to do good for society, all start-ups within this study get regularly and proactively involved with stakeholders related to their business. Their responsive strategy is based on environmental and social assessments combined with stakeholder management. Although these are all, again, informal and hardly systematic mechanisms, all of the start-ups do this within their own networks. For instance, three out of the five start-ups are operating in the medical field, and as such, they move mainly in networks where universities, hospitals, medicine producers, medical-related nonprofit organizations, professors, and medical specialists are represented. The two start-ups that operate in a technical environment deal with architects, chemical manufacturers, laboratories, and building corporations. All of this is specific to the line of business. What all start-ups had in common is that by involving themselves with stakeholders, they learn their needs, demands, 
and trends and receive feedback, which they use to improve and to customize their product features to those needs. The informal mechanisms used to get involved with stakeholders are mostly unplanned and happen more coincidentally than in a planned way. Only one out of the five start-ups attends network gatherings where the respondent makes a connection with all kinds of people (stakeholders), mainly to grow its network of potential buyers, investors, and people who can or could help out in the future.

\begin{tabular}{|c|c|c|c|c|c|}
\hline \multicolumn{6}{|c|}{ Variable: Stakeholder vs Social Capital Theory } \\
\hline Topic & NL1 & NL2 & NL3 & NL4 & NL5 \\
\hline CSR Definition & Social Capital & $\cdot$ & $\begin{array}{c}\text { Both Stakeholder and Social } \\
\text { Capital Theory }\end{array}$ & Social Capital & \begin{tabular}{|c|}
$\begin{array}{c}\text { Both Stakeholder and Social } \\
\text { Capital Theory }\end{array}$ \\
\end{tabular} \\
\hline CSR Identification mechanism & Social Capital & $\cdot$ & Social Capital & $\begin{array}{c}\text { Both Stakeholder and Social } \\
\text { Capital Theory }\end{array}$ & $\begin{array}{c}\text { Both Stakeholder and Social } \\
\text { Capital Theory }\end{array}$ \\
\hline CSR dialogue (with who) & \begin{tabular}{|c|} 
Both Stakeholder and Social Capital \\
Theory
\end{tabular} & . & $\begin{array}{c}\text { Both Stakeholder and Social } \\
\text { Capital Theory }\end{array}$ & \begin{tabular}{|c|} 
Both Stakeholder and Social \\
Capital Theory
\end{tabular} & \begin{tabular}{|c} 
Both Stakeholder and Social \\
Capital Theory
\end{tabular} \\
\hline CSR Considerations & $\begin{array}{c}\text { Both Stakeholder and Social Capital } \\
\text { Theory }\end{array}$ & . & $\begin{array}{l}\text { Both Stakeholder and Social } \\
\text { Capital Theory }\end{array}$ & $\begin{array}{c}\text { Both Stakeholder and Social } \\
\text { Capital Theory }\end{array}$ & $\begin{array}{c}\text { Both Stakeholder and Social } \\
\text { Capital Theory }\end{array}$ \\
\hline CSRi Impact & \begin{tabular}{|c|} 
Both Stakeholder and Social Capital \\
Theory
\end{tabular} & . & Social Capital & Social Capital & $\begin{array}{c}\text { Both Stakeholder and Social } \\
\text { Capital Theory }\end{array}$ \\
\hline CSR form Identification & Social Capital & $\begin{array}{l}\text { Both Stakeholder and Social } \\
\text { Capital Theory }\end{array}$ & $\begin{array}{l}\text { Both Stakeholder and Social } \\
\text { Capital Theory }\end{array}$ & $\begin{array}{c}\text { Both Stakeholder and Social } \\
\text { Capital Theory }\end{array}$ & $\begin{array}{c}\text { Both Stakeholder and Social } \\
\text { Capital Theory }\end{array}$ \\
\hline CSR enables \& barriers Identification & $\begin{array}{c}\text { Both Stakeholder and Social Capital } \\
\text { Theory }\end{array}$ & . & $\begin{array}{l}\text { Both Stakeholder and Social } \\
\text { Capital Theory }\end{array}$ & \begin{tabular}{|c|}
$\begin{array}{c}\text { Both Stakeholder and Social } \\
\text { Capital Theory }\end{array}$ \\
\end{tabular} & - \\
\hline CSR Priorities & Social Capital & $\begin{array}{l}\text { Both Stakeholder and Social } \\
\text { Capital Theory }\end{array}$ & $\begin{array}{l}\text { Both Stakeholder and Social } \\
\text { Capital Theory }\end{array}$ & $\begin{array}{c}\text { Both Stakeholder and Social } \\
\text { Capital Theory }\end{array}$ & $\begin{array}{c}\text { Both Stakeholder and Social } \\
\text { Capital Theory }\end{array}$ \\
\hline CSR Communication & Social Capital & Not Communicated & $\begin{array}{l}\text { Both Stakeholder and Social } \\
\text { Capital Theory }\end{array}$ & Not Communicated & Not Communicated \\
\hline CSR Responsive Strategy & Social Capital & $\begin{array}{l}\text { Both Stakeholder and Social } \\
\text { Capital Theory }\end{array}$ & $\begin{array}{l}\text { Both Stakeholder and Social } \\
\text { Capital Theory }\end{array}$ & $\begin{array}{c}\text { Both Stakeholder and Social } \\
\text { Capital Theory }\end{array}$ & $\begin{array}{c}\text { Both Stakeholder and Social } \\
\text { Capital Theory }\end{array}$ \\
\hline
\end{tabular}

Figure 5. Coding results for CSR engagement.

Regarding communication about CSR engagement and achievement, only one of the five start-ups communicates progress, findings, and news internally through informal gatherings and externally through a newsletter distributed within its network. Most start-ups in this study do not communicate their CSR engagements externally, they do not have any disclosure strategy or means other than some scattered information regarding practices on their websites.

One start-up, for instance, has gotten some media attention, but that was more because it visited a fair where it won several prizes, which resulted in external exposure. If this had not happened, it would not have gotten this kind of exposure.

During the analysis of the interviews, it became clear that to achieve their goal, each respondent mentioned engagement within networks of mutual acquaintance and recognition to pursue shared objectives. The medically oriented start-ups moved in networks of hospitals, doctors, and market-specific organizations, whereas the more technically related start-ups moved in networks allied with their technology. All respondents in this study apply a responsive strategy, which is based on environmental and social assessments, but in a very unstructured and informal manner. The start-ups in this study did not a formal structured mechanism which would enable them to structurally and proactively capture and learn about new and/or changes and contingencies from their respective business environments. Encounters with stakeholders happen due to coincidence, for instance when they learn about an event via their network or get media attention because they visited a fair. One other nice example given by one of the interviewees was the sudden encounter of an ethical dilemma during a business visit to India. During that visit, the interviewee was faced with construction workers engaging in life-threatening antics during assembly of their products. This interviewee expressed his thoughts in the following way: "Then you think, Jesus, I do not want this. This is unsafe and what do I have to do with this situation? How to deal with this situation?" In that particular moment, the interviewee of this start-up realized that there must be a CSR policy to deal with this kind of CSR dilemma.

At the same time, each respondent mentioned that economic objectives are as important as being engaged in CSR, as they all feel the pressure from their investors, who do want a return on their investment. They all start with a brilliant idea (a revolutionary technology to produce something faster, to diagnose faster and better, or to help infants in the early days of their lives), but in the end, one of 
the objectives is making money as well. That is a primary objective in becoming a financially healthy and sustainable firm. Each start-up in this study understands that making a profit enables it to stay engaged in CSR through business objectives and at the same time explore new CSR initiatives and engage in new CSR initiatives.

What also became evident from the interviews is that these start-ups communicate to the outside world on a very limited scale about their CSR performance, engagement, and initiatives. Except for what is on their websites and an occasional newsletter, which one of the start-ups does, nothing else is broadcast on a structural basis. It almost seemed that these start-ups are modest about their vision and would rather not broadcast their message too loudly. As one respondent put it: "It is important to have a green and sustainable positioning, but to broadcast that loudly on a website? To me, that would be counterproductive in my opinion." It almost seemed that they want to be modest about their achievements or their ambitions. They also feel that this is not something a consumer is waiting for or that is the deciding factor for a customer in choosing their product over their competitors.

On the basis of the results outlined above, we propose that the CSR engagement of start-ups is based on a combination of financial and social capital. The evidence from the interview data was in line with the theory of social capital, which refers to connections between individuals, such as trust, norms, and networks [51], and engagement within networks. At the same time, the evidence suggests that financial benefits are a continuous motivator for CSR engagement from inception.

\subsection{Proposition 2: The Business Case for CSR}

In this subsection, the case findings and comments made by the interviewees with respect to the business case for CSR are presented and explored. The research suggests that the decision to engage in CSR is treated as an investment decision with a cost-benefit analysis. Deciding to engage in CSR is for all cases done in an informal manner between the respondent interviewees and the other start-up employees. None of the start-ups has a formal documented decision process. Again, this is in line with ref [12]'s research, which argued that informal CSR strategies prevail among micro-, small-, and medium-sized enterprises. Reasons as to why the start-ups do not have formal processes are mainly that every start-up in this study is spending all of their time making the business a success. Not everything that takes extra time and does not really add value can be done, simply because there is a scarcity of time. This is not surprising, as these start-ups are in general managed by their owners and are largely dependent on internal resources [12]. Start-ups lack formal tools because they require, among other things, an investment of time and the competence to implement these new routines, which start-ups are not ready to provide.

The first check in the decision process that every interviewee mentioned is whether the CSR initiative on the table fits with the company's strategic intentions, mission, and vision. This was important for every interviewee in this study. When the CSR initiative did not fit within the strategic goals, all interviewees commented that they would not engage in that particular CSR initiative. If a CSR initiative fits the strategic goals, different approaches to a risk assessment are applied. In the interviews, one could distinguish two main parts in assessing the risks attached to CSR engagement, one being business process-related and the other part being about technical/technology processes.

One out of the five cases assesses the business risks attached to CSR engagement by doing a financial risk analysis and a business risk analysis by using the Strengths, Weaknesses, Opportunities, and Threats Analysis (SWOT technique) and Market Attractiveness Business position Assessment (MABA technique). Two of the five start-ups assess their technical risks by using the failure mode and effect analysis (FMEA) technique. A failure mode and effects analysis is a highly structured, systematic technique that uses inductive reasoning (forward logic) for a failure analysis, which involves reviewing components, assemblies, and subsystems to identify failure modes and their causes and effects. For each component, the failure modes and their resulting effects on the rest of the system are recorded in a specific FMEA worksheet. 
The remaining three other cases perform risk assessments from a more rational point of view (in an informal way using no formal technique), as mentioned before. One start-up does not apply any risk assessment, relying on expertise from other parties in the network.

In deciding what kind of resources and what budget should be assigned, all cases were totally aligned. All start-ups refer primarily to their financial situation first. There must be a financial basis somewhere: making a profit first is important. Once that happens, the start-ups can start giving something back to society, because every single start-up commented that they feel pressure from their investors, as they want to see returns on their investments. Making money, for all of these start-ups, enables them to reach their further goals. One of the start-ups has even formalized this in its investment memoranda, which have been signed by all parties and which enable them to set up a foundation to put the benefits of their product into developing countries. When looking at what the start-ups then actually do for society, one notices a full range of CSR activities. All start-ups in this study provide expertise, knowledge, and time related to their own line of business to their networks, groups, and communities, regardless of the lack of financial benefits. Two out of the five start-ups even provide their product to the community to increase the look and feel of it or to give the community an opportunity to work and gain experience with their product, because all can benefit then.

All of the previous decision considerations discussed are reasoned from a rational point of view, whether informally or formally. One start-up from these five also considers an emotional plane in the decision to engage in CSR. This implies that the CSR initiative should also have a personal fit, which is put on the same level of consideration to assess whether it fits strategically. This means that even when a CSR initiative fits the strategic intentions, a decision could still be made against implementing it if it does not feel right. During the interviews, the researchers only encountered this comment from one start-up, and not from the other start-ups. This does not mean that the other start-ups have similar emotional considerations, but this could be, in general, a consideration every start-up makes when confronted with a CSR initiative. Figure 6 shows the results after coding the data according to the coding framework in Appendix B.

\begin{tabular}{|l|c|c|c|c|c|}
\hline Variable 2: The Business Case for CSR & \multicolumn{1}{l|}{ NL2 } & NL3 & NL5 \\
\hline Topic & Informal process & Informal process & Informal process & Informal process & Informal process \\
\hline CSR Decision & $\begin{array}{c}\text { Partly formal and partly informal } \\
\text { process }\end{array}$ & $\cdot$ & Formal process & Informal process & Informal process \\
\hline CSR Risk Assessment & Informal process & Informal process & Informal process & Informal process & Formal process \\
\hline CSR Riesources & Informal process & Informal process & & Informal process & Informal process \\
\hline CSR Budget & Informal process & Informal process & Informal process & Formal process & Formal process \\
\hline CSRi Impact & & &
\end{tabular}

- No coding possible due to insufficient information

Figure 6. Coding results for the business case for CSR.

It was clear from the interviews that every start-up studied in this research has incorporated CSR into its processing or products, which was achievable through the use of technology that comprises smart and accurate diagnostics or with the help of a revolutionary approach to the energy conversion problem. While addressing the concerns for people and for the planet, start-ups have incorporated CSR initiatives into their products or services as a competitive edge for first-time potential customers. While communicating about their CSR practices and engagement, the respondents become self-conscious, because customers can perceive such communication as vain and thus migrate to a competitor with more substantiated CSR.

For instance, according to one interviewee, "It is important to have a green and sustainable positioning, but to broadcast or disclose this would be, in my opinion, counterproductive. The more marketing around your CSR engagement the less the customers would think that you are true and not just window-dressing." 
Once they have achieved financial strength, firms can return back to societal good in future projects. Start-ups, after building a sound financial base, can help infants in countries where medical facilities are not mature, such as in the Netherlands. For better service to customers, some start-ups hire third parties to speed up processes such as the removal of contamination or making a product more suitable: all of these are proactive actions for giving back to society.

As discussed earlier, profit-making is a major goal of start-ups and is the foremost reason for shareholders to invest, as was mentioned by one respondent,

"At a certain moment there is a new investment project and when you want to implement that immediately with socially responsible matters, the investor says: Well, just wait a minute! You get this money from me to ensure that the product comes on the market and the company is going to flourish. Not to spend the money on CSR."

This proves that gaining a competitive advantage is the only reason for incorporating CSR into a business model; moreover, CSR engagement is used first for making a profit. As another respondent said, "When we will start making profit then we will return to give back something to society by engaging into CSR."

Therefore, financial strength is a prerequisite for the business decision to incorporate CSR, because profit-making can assure a basis for upcoming CSR initiatives. Furthermore, most respondents supported this assumption that the main objective is to develop, manufacture and to sell product, which enables the possible support for CSR goals and events. For a better understanding of the above-mentioned scenario, a few respondents use risk assessment techniques such as FMEA, SWOT, and MABA, though there is a lack of formal processes (the majority assess these risks through informal reasoning). One reason for start-up executives not using these risk assessment techniques is the fact that they are not available, as mentioned by the interviewees: "I have seen these risks analyses before, but I do not know if I could do that myself. We are not specialists in that area, but we got some comments from an architect, a mechanical engineer and the factory. I am convinced that if we did it now that it would benefit our product." The start-ups who use risk assessment techniques have had previous experience using them, while other start-ups who are pro- or anti-CSR initiatives make decisions based only on common sense or gut feelings, ignoring the calculations.

Thus, based on case data, we propose that the decision to engage in CSR is treated as an investment decision, and a few executives use informal assessment techniques such as cost-benefit analyses in deciding how to proceed with a particular CSR initiative. A few of the interviewees even argued that the decision to incorporate CSR into the business model is based on the financial perspective, which prevails in any business venture.

\subsection{Proposition 3: CSR Theater}

In this subsection, the comments made by the interviewees with respect to the CSR theater are presented along with case data. The business values among the cases in this study ranged from philanthropic to transforming the ecosystem to reengineering the value chain. All start-ups analyzed have formulated their CSR engagement around two pillars. The first pillar (philanthropic) is rooted in the entrepreneur's personal priority and concern for addressing a social and/or environmental need (because it is a good thing to do), without the need for immediate business profit.

The second pillar (reengineering the value chain) is about co-creating with a primary focus on incremental and self-interested increasing profits. The third pillar (transforming the ecosystem) is rooted in the awareness of shareholders who want to see a return on their investment. This means that while CSR focuses on and addresses social and/or environmental needs, it should somehow contribute to the financial bottom line.

Figure 7 shows the coded data regarding the decision to engage in CSR (coding according to the coding framework in Appendix B). 


\begin{tabular}{|c|c|c|c|c|c|}
\hline$\overline{\text { Topic }}$ & NL1 & NL2 & $\mathrm{NL3}$ & NL4 & NL5 \\
\hline CSRDefinition & $\begin{array}{l}\text { Combi of Transforming Ecosystem } \\
\text { and Reengineering Value Chain }\end{array}$ & Philanthropic & Transforming Ecosystem & $\begin{array}{l}\text { Combi of Transforming } \\
\text { Ecosystem and } \\
\text { Reengineering Value Chain }\end{array}$ & $\begin{array}{l}\text { Combi of Philanthropic and } \\
\text { Transforming Ecosystem }\end{array}$ \\
\hline Respondent Importancy to CSR & Transforming Ecosystem & Philanthropic & Philanthropic & Philanthropic & Philanthropic \\
\hline CSR initiatives & Transforming Ecosystem & Reengineering Value Chain & Philanthropic & $\begin{array}{l}\text { Combi of Transforming } \\
\text { Ecosystem and } \\
\text { Reengineering Value Chain }\end{array}$ & Transforming Ecosystem \\
\hline CSR Objectives & $\begin{array}{l}\text { Combi of Transforming Ecosystem } \\
\text { and Reengineering Value Chain }\end{array}$ & Transforming Ecosystem & Transforming Ecosystem & Transforming Ecosystem & $\begin{array}{l}\text { Combi of Transforming } \\
\text { Ecosystem and } \\
\text { Reengineering Value Chain }\end{array}$ \\
\hline CSR Rationaly & Reengineering Value Chain & Philanthropic & Philanthropic & Philanthropic & $\begin{array}{l}\text { Combi of Philanthropic and } \\
\text { Rengineering Value Chain }\end{array}$ \\
\hline CSR Implementation & Reengineering Value Chain & Transforming Ecosystem & Transforming Ecosystem & $\begin{array}{l}\text { Combi of Transforming } \\
\text { Ecosystem and } \\
\text { Reengineering Value Chain }\end{array}$ & Philanthropic \\
\hline CSRiRieporting & No Reporting & No Reporting & No Reporting & No Reporting & No Reporting \\
\hline CSR Lessons Learnt & Transforming Ecosystem & . & Transforming Ecosystem & Transforming Ecosystem & Reengineering Value Chain \\
\hline CSRDriving Forces & Philanthropic & Philanthropic & Philanthropic & Philanthropic & Philanthropic \\
\hline
\end{tabular}

Figure 7. Coding results for CSR theater.

Three out of five cases were concerned with improving the operational effectiveness of producing their product and trying to use environmentally friendly materials and (electronic) components that support the third pillar (transforming the ecosystem). For instance, one start-up developed an alternative, more efficient, and less damaging technology to extract substances from plants, which is less stressful to nature. This means chemical variants would no longer be needed, waste materials would be less, and the need to dispose of items would be less.

The other cases try to limit their footprint by outsourcing noncore activities, such as outsourcing product assembly by collaborating with groups from their own network. They understand that everybody ultimately benefits, which creates win-win opportunities.

Furthermore, all start-ups have initiatives that support the philanthropic pillar. These initiatives range from making expertise and knowledge available to new start-ups, to making technology accessible for law enforcement agencies to track doping or pollution violations, to making a product available to end-users who can experience firsthand how the product works in the environment.

However, one can have all good intentions, but in the end, the stakeholders decide for an initiative or against it. To do less harm to the environment, one start-up opted initially for a recyclable product. This initiative was declined due to a high risk of infections, which resulted in an adaption of the product to satisfy the stakeholders' wishes, meaning a non-recyclable product.

None of the cases in this study report their CSR engagements. Three out of five start-ups eventually have to report CSR because of medical regulations and the wish to become an ISO-certified company. However, there is no authority who asks for it, according to one start-up, and another start-up even commented that it does not seem to be a factor in a customer's choice to decide for their product instead of a product from their competitor.

A company can be active in one or all three theaters: the "philanthropic" theater, the "transforming the ecosystem" theater, or the "reengineering the value chain" theater. From the interviews, it became clear that all of the start-ups are active in at least two out of the three theaters, but not all of them act in the same pair of two theaters. The field they operate in together with the personal drive of the entrepreneur greatly determine in which theaters they act. What cases seemed to have in common were philanthropic driving forces. Relevant quotes from the interviewees stressed that for start-ups, it is important that "the world becomes safer and to prevent that the community is fooled", or "a successful business is where you are not only good for your own investors, but that you also serve the community", or "somewhere we are idealists, we want to make a positive contribution to the energy transition". These examples seem to fit into the philanthropic theater, which is driven by the 
entrepreneur's personal, social, and environmental priorities, while at the same time addressing social and environmental topics. What also became evident from the interviews is that CSR policy is not something that is assigned officially to one person. It is more the collective values the employees bring into the start-ups: "At this moment CSR is not specifically assigned to someone. It is more from our own intrinsic value." (undisclosed interviewee).

It was noticed that every start-up has developed a business strategy to initiate CSR engagement that is related to its own field of expertise, whether medical or technological. Here, it was noticed that several start-ups address critical social and environmental needs, which fits the "transforming the ecosystem" theater [33]. One respondent gave a nice example that fits this theater: "Premature babies are nowadays monitored through sticky pads which have to be replaced regularly. Our product replaces the sticky pads, it's a belt which goes on once and monitors everything". This is an example that is fundamentally disruptive to the existing value chain, which requires risk-taking and a focus on long-range rather than short-term economic gains.

In addition, some of the start-ups have employed CSR engagement primarily focused on improving operational effectiveness throughout the value chain, which fits the "reengineering the value chain" theater [33]. One respondent gave a nice example that fit this theater,

"The big advantage is that the source of raw materials is not damaged. You can continue to use the same plant repeatedly. Especially the growth and recovery process of such plant is the most expensive. In addition, this extraction method is with respect to energy and waste much more sustainable and efficient than the current methods. Waste materials are less and need to be disposed of with less transportation and costs. Our method is also cheaper, which means that medicines are also more easily accessible for certain target groups."

On the basis of the case results, we propose that the business values of a start-up determine its CSR engagement. The philanthropic drive of a start-up determines its CSR initiatives, which are then in line with the field the start-up is operating in.

\subsection{Proposition 4: Entrepreneurial Orientation}

In this subsection, the data and comments made by the interviewees with respect to entrepreneurial orientation are presented and explored. Figure 8 shows the coded data regarding entrepreneurial orientation and experience (coded according to the coding framework in Appendix B).

\begin{tabular}{|c|c|c|c|c|c|}
\hline Topic & NL1 & NL2 & NL3 & NL4 & NL5 \\
\hline Frevious CSR experience & $\begin{array}{l}\text { Yes, in the field of business } \\
\text { processes with incubators by using } \\
\text { my knowledge }\end{array}$ & $\begin{array}{l}\text { No, worked in the postal } \\
\text { delivery and later in sales, and } \\
\text { company manager }\end{array}$ & $\begin{array}{l}\text { Yes, from a distance in a } \\
\text { marketing capacity. Had to } \\
\text { communicate policy on CSR }\end{array}$ & $\begin{array}{l}\text { No, came straight from } \\
\text { education into this start-up }\end{array}$ & $\begin{array}{l}\text { Yes, dealt with CSR from a } \\
\text { distance though. Not my } \\
\text { primary tasks }\end{array}$ \\
\hline Employment Years & 22 employment years & 40 employment years & 35 employment years & 4 employment years & 30 employment years \\
\hline Educational background & University: Technical physics & Lower Technical School & University: Master Marketing & $\begin{array}{c}\text { Technical College: Laboratory } \\
\text { and Engineering }\end{array}$ & $\begin{array}{l}\text { University: Chemics, and } \\
\text { Marketing Course }\end{array}$ \\
\hline Age Category & Age: 47 & Age: 56 & Age: 57 & Age: 27 & Age: 52 \\
\hline
\end{tabular}

Figure 8. Coding results for entrepreneurial orientation.

The interviewees from the different start-ups had diverse employment backgrounds, employment years, and previously gained CSR-related experience. There was one interviewee who had 22 years of background in the field of product development, process development, and business development. During this employment period, the interviewee incurred firsthand CSR experience internally and externally with suppliers. Another interviewee worked 35 years in communication and marketing roles within a big international company. During this period, the interviewee gained CSR experience from a distance, having a role that incorporated communicating the CSR policy to customers and suppliers. Another interviewee worked for 40 years in the postal delivery sector and later in marketing for a caravan and camper business. Unfortunately, this interviewee did not encounter any CSR experience during this employment. There was also an entrepreneur that came straight from school to the start-up, 
having gained no CSR experience whatsoever. In addition, the last entrepreneur was employed for 25 years in the laminate market, but also did not have anything to do with CSR-related initiatives. Although it played a role in the market, the interviewee was not involved. Surprisingly, regardless of any extensive employment record, age (which ranged from 27 to 57), and educational background (which ranged from lower technical school to university), all interviewees showed intrinsic personal drive and an eagerness to become engaged in CSR (even the interviewee who came straight from school to the start-up).

One proposition states that the more experienced an entrepreneur is, and the more an entrepreneur exhibits expertise, the more he/she acts in engaging with CSR. During the interviews, it became clear that, when talking about the entrepreneurial CSR experience in past employment and in terms of expertise gained, there was no clear link with CSR engagement.

The respondents in this study had gained work experience in completely different branches, varying from technical backgrounds to sales backgrounds. Gaining work experience in itself has contributed to how they act, to how they feel about their professional contributions, and to building expertise, but it does not explain whether they behave in a socially responsible way. All respondents in this study definitely gained expertise in their fields, but did not necessarily gain expertise in CSR. Some respondents in this study indirectly or directly dealt with corporate social responsibility, but there were also respondents who, in their previous work, were not engaged in CSR at all. There was even one respondent who came straight from school to the start-up, the youngest entrepreneur in this study. Still, all interviewees have incorporated CSR into their business, and some have even chosen their work environment to fit their personal drive to give something back to society. One interviewee expressed this nicely, "That is also one of the reasons that I opted for this company. I wanted to apply my knowledge and expertise in an environment that really contributes to society."

The researchers also probed the educational background of the interviewed entrepreneurs.

Some entrepreneurs in this study had a university degree, others had technical college, and one entrepreneur had finished the lower technical school. The results from this research show that it did not matter what training they had done in the past or what refresher course they had received in terms of engaging or not engaging in socially responsible entrepreneurship.

On the basis of the case and interview data, we propose that the entrepreneurs' willingness to adopt CSR practices was determined by their personalities and organizational expertise and experiences. Our findings show that despite the fact that every respondent in this study had a different background, age, or level of education, the interviewee still engaged in CSR. This does not mean that expertise and experience must be ruled out as factors that positively influence CSR engagement. It sure does make it easier to engage in CSR when you have gained experience in the past with CSR engagement, but there must be something additional to having experience and expertise. When asked the question of why they were engaged in CSR, all respondents mentioned that they had a personal drive to act in a socially responsible way. As one respondent described, "You have to believe in it. It must fit with your inner drive. It must be at your heart. There must be passion." Even the youngest entrepreneur explained it as follows,

"You must always be aware of what you leave behind and what effect you have with your company on others, on the society, on future business partners. You need to perform your business activities in a very sustainable way so that you think about the future; about new generations to come. The opportunity to work with something so vigorous and thereby contribute to a more sustainable society is the motivation to do this."

This shows the importance of an additional factor that positively influences CSR engagement in a start-up: the intrinsic values and drive of the entrepreneur in CSR engagement. This is independent of age, experience, or educational background. Whether this is more important than experience or expertise is something we cannot say, as this was not investigated. 


\section{Discussion}

On the basis of our cases and data analysis, we propose that the decision to engage in CSR is treated as an investment decision. The business values of a start-up determine its CSR engagement. The philanthropic drive of a start-up determines its CSR initiatives, which are then in line with the field the start-up is operating in. The entrepreneurs' willingness to adopt CSR practices is determined by their personalities and organizational expertise and experiences. CSR engagement in the business model of start-ups is based on a combination of financial and social capital, while financial benefits are a continuous motivator for CSR engagement from inception into the business model.

Start-ups explore a CSR relationship based on a combination of the stakeholders' perspectives and social capital, a finding that is in accordance with ref [8]. The start-ups are aware of their environment and their role in the community, and they try to create a collective value with their counterparts. Different views on stakeholder interaction were found. Some start-ups had developed a sort of mechanism to interact with stakeholders, and some were scarcely structured and were based on informal interactions. They manifested an unwillingness to formalize into specific and explicit processes in order to maintain highly informal connections based on trust and norms within their own segment-related networks. As such, they all balance CSR demands with their vision and mission, including demands from their investors.

In accordance with ref [7], the start-ups are dependent on the direct economic benefits of CSR-oriented strategies. The interviews revealed that the start-ups had a prevailing focus on their financial situation, which means that they want to secure their license to operate in the communities they target to serve through their CSR practices. When there is no financial backbone, there is no opportunity to engage in CSR. Before a new business endeavor, the risks associated with finance, technology, and technical aspects are assessed (some through a more structured assessment than others): in essence, they have the same objective, which is to integrally connect social and economic goals in the business vision and mission [4]. The cost-benefit analysis mechanisms used to assess alignment with mission and vision were scarcely structured, unplanned, and unsystematic. In line with ref [12], informal processes prevailed among the start-ups. Yet, the start-ups in this study follow a proactive cost-benefit calculus that factors in financial gains, as argued by ref [7]. That is, they engage with CSR strategies and implement CSR practices with an important impact on the bottom line. Furthermore, the start-ups, which were oriented toward the medical field, are the most structured in their approach to CSR, as it is demanded from notified bodies and stakeholders that need to release a product fit for use. These demands are rigorous, and without meeting their requirements, the product developed by the start-ups would never be considered on the market. These notified bodies and stakeholders demand, for example, a structured risk analysis according to ISO norms and risk analysis techniques such as failure mode and effect analysis (FMEA). This is not generally common among start-ups, as it requires knowledge, expertise, and an investment of time that start-ups are not ready to provide. However, despite the liability of their newness, start-ups from the medical sector undergo the requirements.

Furthermore, in accordance with ref [33], the motivation for CSR engagement of the start-ups interviewed in this study fall under different arenas: the start-up entrepreneurs have their own drive, interest, and commitment to CSR. This means that the adapted CSR strategy is highly personalized. However, when interviewees were asked how important it is that their start-up is operating in a socially responsible way and what were the driving forces behind CSR engagement, the comments received indicated a philanthropic-oriented theater. They all started with arguments towards CSR such as doing good for society and the environment without mentioning anything about future business profits. They started off as "ideologists" with great ideas and intentions. Then they dove into reality, discussing pressure from investors, treating CSR engagement as an investment decision, and focusing on financial growth. From this moment onwards, the motivation for CSR engagement showed a clear shift toward either "transforming ecosystem" or "reengineering value chain". This seemed to be equally distributed. 
It seems that the initial business choice, based on the entrepreneurs' true intentions for their businesses, was logically accommodated by their CSR practices.

Ref [39] argued that the more experienced an entrepreneur is, and the more an entrepreneur possesses expertise, the more likely he/she is to engage in CSR. The results from this study are not in accordance with that study. The interviews with the participants revealed that the experience and the expertise of the entrepreneur were not related to more intensive CSR engagement. Entrepreneurs with outstanding accomplishments were not more prone to engage in CSR practices. What all of the start-up entrepreneurs had in common, independently of age, employment record, and previous companies worked for, was personal drive, commitment, and interest in doing good for society. From this, we propose that personal drive and the intrinsic characteristics of the entrepreneur are more relevant to CSR engagement than are experience and expertise.

Furthermore, the findings for the measurement "CSR engagement" were inconsistent with ref [8], which promoted a combination of both the theory of stakeholder perspectives and the theory of social capital to determine the relationship between start-ups and CSR engagement. Being new to an existing market, start-ups need to consider both perspectives to overcome the liability of newness and become financially healthy. However, divergent mechanisms are used in practice to bring together all stakeholder needs. Specifically, this study contributes to understanding how start-ups act in a society with several stakeholder demands while they strive to remain healthy economic firms.

Start-ups tend to be more vulnerable to economic losses and will thus be more dependent on the direct economic benefits of CSR-oriented strategies, thus treating CSR as an investment decision and focusing on the financial balance sheet. The findings show that start-ups use official techniques to extract the information needed to make a proper decision based on a supply and demand model that determines the appropriate level of CSR investment (consistent with ref [8]).

\section{Conclusions}

\subsection{Limitations of the Study}

It is important to recognize that there are some limitations that need to be considered when interpreting the findings of this study.

First, this research was conducted as an exploratory multiple-case-study design, and the aim of the research was to gain insight into underlying drivers of CSR engagement in the business model of start-ups by investigating meaningful characteristics of the organizational processes, managerial processes, and surrounding expectations. The reason we chose a multiple-case-study approach was to replicate or confirm results not only in a single start-up but also in multiple start-ups. This resulted in five start-ups representing different market segments. That is, the start-ups in this study were not restricted to a specific industry or market segment, which is something that makes it difficult for researchers to make claims that can be considered generalizable [40]. The generalizability of any study is constrained by the nature of the sample [52], so the sample used in this study is not appropriate for drawing wider inferences.

Secondly, the social desirability and objectivity of the researcher could also be considered limitations or reliability constraints. This is usually the case for face-to-face interviews. There is a limitation based on interview bias due to the influence of the researcher on the responses of the participant. That is why the researchers created a coding scheme. Analyzing the data by means of a coding scheme reduced the possibility of biasing participants' responses and additionally overlooking possible important issues. It furthermore gave insight for other researchers into how the content analysis was done.

For the conclusions of this research, a number of methodological limitations must be taken into account. A general limitation of qualitative research is low reliability [46]. For this research, an attempt was made to have the interviews proceed according to a certain structure, but there was also room for the respondent to give examples or to report on certain events. It also appeared that certain terms and the wording of some questions were not always clear, e.g., the "role of risk reduction" or "cause 
marketing". The validity of qualitative research can be high [46], but the external validity for this study is not very high given the small sample population. Internal validity and reliability were guaranteed as much as possible through the choice of the research design and a structured, phased approach to the analysis process.

\subsection{Future Lines of Research}

The following starting points for further research can be deduced from the results of this research. First, more knowledge about what social start-ups can achieve is important for governments and policymakers. This form of social impact should not be seen as a threat, but as a means. To this end, whether the social start-ups are sustained and what impact they are able to continue to achieve should be investigated on a longitudinal basis. It seems that these start-ups fill in the niches where governments fail and at the same time serve the interests of governments as well as stakeholders. This leads to a paradox between government tasks and social entrepreneurship, whereby the government promotes social entrepreneurship, but social entrepreneurship is a result of too little attention being paid by the government to its own responsibilities. More research is needed to see how this mechanism works. Another recommendation for further research is analyzing the social impact that can be achieved through entrepreneurship. The ability to market the impact may be a condition for social movements to succeed. Finally, mutual, effective coherence between CSR elements in order to arrive at a business model should therefore become more transparent.

Furthermore, this study was conducted among Dutch-based start-ups from a few industry sectors. Further work on CSR engagement by start-ups could focus on start-ups from market segments other than the ones that participated in this study. Further research could also extend to other countries. A certain degree of differentiation between start-ups based in other countries might occur due to different normative, cognitive, and regulative pillars influencing CSR [13].

Another suggestion for future research is related to whether the decision to engage in CSR is treated as an investment decision. Findings from this study showed that all start-ups performed a cost-benefit analysis. The entrepreneurial feeling about CSR engagement was for some start-ups equally important to the cost-benefit analysis. Our study puts forward that the intrinsic values and drive of the entrepreneur influence CSR engagement. This was not specifically investigated in-depth, but it would be worthwhile to take this on board in future research, focusing on how the entrepreneur's feelings, intrinsic characteristics, and drive are relevant to CSR investment decisions.

\subsection{Managerial Recommendations}

This paper brings new insight into the practice of CSR and adds to the literature. Ref [53] argued that the holy grail of CSR is an illusion. Although this conclusion refers to already established and often large companies, the holy grail of CSR can become a reality for social start-ups. That is, three out of four cases had conquered a position in the market and were showing organizational growth. Their targeted, hands-on approach and the valuable, direct creation of impact played an important role. Thus, this outcome can contribute to the discussion about the existence of a business case for CSR, which is still a vexed subject in the economic literature $[37,53]$.

This section will emphasize some practices seen during the interviews with the entrepreneurspractices that stood out to the researcher or were mentioned by the entrepreneurs as advice to other start-ups, as these practices could enhance their positioning in the market or enable value co-creation with stakeholders.

Among start-ups, there was a scarce, unstructured, and informal way of engaging in CSR due to a lack of a formal CSR strategy. CSR entailed disparate CSR initiatives without an overarching umbrella. The researcher argues that a firm maximizes its CSR effectiveness based on a coherent strategy that is practical and logical within its field of operations, representing a forward-thinking approach to crafting strategic CSR. This helps a company to manage and effectively address social or environmental problems together with a clear CSR prioritization framework for future CSR demands 
from stakeholders. While there are no one-size-fits-all strategy models, there is a way forward for strategic CSR: auditing, editing, and developing. In the auditing step, a company needs to categorize its CSR initiatives into one of the three CSR theaters and then move forward with the programs that fit the bottom line. That is, the firms need to account for the social and environmental impact and the resulting effectiveness of the initiatives. This requires evaluating both the positive and the negative effects of the company's manufacturing and operating activities and what the net cost is to the natural environment and the people/stakeholders affected by the business. Crafting a comprehensive and cohesive CSR strategy requires a company to relate to its various initiatives. Finally, the last step is to create CSR social and environmental value while supporting a company's business objectives, reducing operating costs, and enhancing relationships with key stakeholders and customers [33].

Start-ups engage in CSR in their own way (based on entrepreneurial personal motives), and they are assessed according to their business mission and vision without any reference to a notified body or guidelines that can be consulted or followed. European guidelines (such as the NEN-ISO-26000-2010 guidance on social responsibility), this international standard provides guidelines for the underlying principles of social responsibility, the recognition of social responsibility and the involvement of stakeholders, the core themes and subjects that are part of social responsibility, and ways to engage in socially responsible behavior. The core themes in this international standard cover a number of topics, and it is the responsibility of each organization to determine, based on their own considerations and through dialogue with stakeholders, which topics are relevant and significant for the organization to address.

Thus, consulting this international guidance on social responsibility would help start-ups to structure their CSR intentions within their business, and at the same time, it could benefit them to become an ISO company. Being an ISO company, or referring to an ISO international standard, and communicating and promoting such a standard to the outside world could influence firms' competitive advantage over rivals and could influence investors, owners, sponsors, and financial institutes. The researchers highly recommend that start-ups take notice of the content of this international guideline (from application to communication) in a proactive and structural manner.

Furthermore, start-ups in general could have low visibility outside the company. Ref [8] calls this approach to CSR "sunken" CSR, meaning that it exists but that it is less formal and most of the time not communicated or shared with the outside world. The researchers, therefore, recommend that start-ups build network relationships with the community, financial institutions, and stakeholders in an active and proactive way, which is illustrated best with a comment made by one entrepreneur, "... maintaining the contact with the stakeholders is vital. Organize information evenings and spare no marketing event. We have to keep drawing on our stakeholder involvement. We must constantly pro-active in letting the world know that we are involved and we are here as part of the community."

We observed in this study that some start-ups use well-known techniques, such as FMEA-SWOTMABA, to assess their business risks and technical risks. These techniques enable and facilitate the decision-making process over CSR-related questions. What we also observed is that one start-up entrepreneur acknowledged that having had that particular experience would have helped in developing an even better and cheaper product. Therefore, the researchers highly recommend that start-ups acquire specific expertise, either through the hiring of an experienced person or through hiring advisors to support them in a particular field. This enables the start-up to be better prepared in mitigating and proactively dealing with CSR hurdles along their journey to becoming a sustainable company.

Author Contributions: Conceptualization, C.L.V. and M.L.; methodology, M.L. and F.R.; software, C.L.V.; validation, C.L.V., M.L., F.R., and N.R.; formal analysis, C.L.V. and F.R.; investigation, M.L.; resources, M.L.; data curation, F.R.; writing-original draft preparation, C.L.V., M.L., and F.R.; writing-review and editing, C.L.V., and F.R.; visualization, N.R.; supervision, C.L.V.; project administration, C.L.V.

Funding: This research received no external funding.

Conflicts of Interest: The authors declare no conflicts of interest. 
Appendix A. The Final Interview Protocol Used during Interviews

\begin{tabular}{|l|l|}
\hline Proposition 1: & Stakeholder- and social capital theory \\
\hline P1.1 & What is the definition of CSR within the firm? \\
\hline P1.2 & $\begin{array}{l}\text { Does your company have a mechanism in place for identification of } \\
\text { stakeholders needs and expectations? }\end{array}$ \\
\hline P1.3 & With what groups did you initiated dialogue? \\
\hline P1.4 & $\begin{array}{l}\text { How are the views of stakeholders considered in deciding for CSR } \\
\text { practices? }\end{array}$ \\
\hline P1.5 & $\begin{array}{l}\text { How is the impact of a particular CSR activity assessed towards their } \\
\text { stakeholders? }\end{array}$ \\
\hline P1.6 & $\begin{array}{l}\text { How is any form of CSR identified within the business (internal / } \\
\text { external)? }\end{array}$ \\
\hline P1.7 & How do you identify CSR enablers and barriers (internal / external)? \\
\hline P1.8 & How are priorities defined? \\
\hline P1.9 & Is CSR performance internally / externally communicated? \\
\hline P1.10 & What is the company's responsive strategy towards CSR? \\
\hline
\end{tabular}

Figure A1. Stakeholder and social capital theory.

\begin{tabular}{|l|l|}
\hline Proposition 2: & Investment decision \\
\hline P2.1 & How does the company decide to engage in CSR practice? \\
\hline P2.2 & Is a risk assessment part of the decision to engage in CSR practice? \\
\hline P2.3 & How are the resources allocated for CSR activities? \\
\hline P2.4 & How is the budget decided for these activities? \\
\hline P2.5 & Is CSR engagements' impact measured, monitored and evaluated? \\
\hline
\end{tabular}

Figure A2. Investment decision.

\begin{tabular}{|l|l|}
\hline Proposition 3: & Business Values \\
\hline P3.1 & How would you defined corporate responsibility? \\
\hline P3.2 & $\begin{array}{l}\text { How important is it for you that your company operate on a socially } \\
\text { responsible level? }\end{array}$ \\
\hline P3.3 & What CSR initiatives are undertaken in your organisation? \\
\hline P3.4 & $\begin{array}{l}\text { What are the objectives of the CSR initiatives undertaken in your } \\
\text { organisation? }\end{array}$ \\
\hline P3.5 & $\begin{array}{l}\text { What is the rationale behind covering the mentioned issues under CSR } \\
\text { in your organization? }\end{array}$ \\
\hline P3.6 & How do you implement CSR initiatives? \\
\hline P3.7 & Does your company report on CSR engagement? \\
\hline P3.8 & What are the lessons learnt from CSR engagement? \\
\hline P3.9 & $\begin{array}{l}\text { What are the main driving forces behind (your companies') these CSR } \\
\text { efforts? }\end{array}$ \\
\hline
\end{tabular}

Figure A3. Business values.

\begin{tabular}{|l|l|}
\hline Proposition 4: & Entrepreneurial experience and expertise \\
\hline P4.1 & Did you had any experience with CSR before you started this firm? \\
\hline P4.2 & Where were you previously employed? \\
\hline P4.3 & What is your educational background? \\
\hline P4.4 & What is your age? \\
\hline
\end{tabular}

Figure A4. Entrepreneurial experience and expertise. 


\section{Appendix B. Category-Labeling Matrix}

\begin{tabular}{|c|c|c|c|}
\hline Proposition & Sub-category & Coding table & Criteria to code 'bits of data' \\
\hline CSR Engagement & & ENG & \\
\hline ENG: Economical & & ENG-ECO & $\begin{array}{l}\text { Being consistently profitable with a strong focus on } \\
\text { maximizing earnings per share. }\end{array}$ \\
\hline ENG: Legal & & ENG-LEG & $\begin{array}{l}\text { Next to ensuring that company is profitable ensuring } \\
\text { that it provides goods \& services that meet minimum } \\
\text { legal requirements, complying with various } \\
\text { regulations and fulfilling legal obligations. }\end{array}$ \\
\hline ENG: Ethical & & ENG-ETH & $\begin{array}{l}\text { Responsibilities that a company puts on itself } \\
\text { because its owners believe it's the right thing to do } \\
\text { which go beyond mere compliance with laws and } \\
\text { regulations. Being a good corporate citizenship by } \\
\text { doing what is expected morally or ethically. }\end{array}$ \\
\hline ENG-Philantropic & & ENG-PHI & $\begin{array}{l}\text { Responsibilities that go above and beyond what is } \\
\text { required or what the company believes is right, by } \\
\text { making an effort to benefit society by participating } \\
\text { voluntary with local communities or projects that } \\
\text { enhance a community's quality of life. }\end{array}$ \\
\hline
\end{tabular}

Figure A5. Labeling for category CSR engagement

\begin{tabular}{|c|c|c|c|}
\hline Proposition 1: Stakeholder vs Social Capital Theory & & THE & \\
\hline THE: Stakeholder & Profit Driven CSR & THE-STA & $\begin{array}{l}\text { Address stakeholder expectations where economic } \\
\text { objectives being most important, where management } \\
\text { choice is a function of stakeholder influences }\end{array}$ \\
\hline THE: Social Capital & Caring Driven CSR & THE-SOC & $\begin{array}{l}\text { Engagement with stakeholders demonstrating } \\
\text { intentions to generate trust, goodwill, solidarity, } \\
\text { building (personal) relationships, embedded within } \\
\text { networks of mutual acquaintance and recognition to } \\
\text { pursue shared objectives of all members }\end{array}$ \\
\hline THE: Stakeholder \& Social Capital & Synergistics Driven CSR & THE-STA \& SOC & $\begin{array}{l}\text { Recognise that economic objectives are important } \\
\text { which is enabled by engaging within networks of } \\
\text { mutual aquaintance and recognition to pursue } \\
\text { shared objectives of all members }\end{array}$ \\
\hline
\end{tabular}

Figure A6. Labeling for category stakeholder/social capital theory

\begin{tabular}{|c|c|c|}
\hline Proposition 2: Investment decision & ID & \\
\hline ID: No & ID-NO & $\begin{array}{l}\text { There is no thought given as to how, when, where and } \\
\text { how much resources (financial, people, knowledge) } \\
\text { will be spend on CSR engagement, nor there has been } \\
\text { done an assessment of potential benefits now or in } \\
\text { the future }\end{array}$ \\
\hline ID: Yes, Formal & ID-YEFOR & $\begin{array}{l}\text { A formal determination as to how, when, where and } \\
\text { how much resources (financial, people, knowledge) } \\
\text { will be spend on CSR engagement, together with an } \\
\text { assessment of potential benefits now or in the future }\end{array}$ \\
\hline ID: Yes, Informal & ID-YEINF & $\begin{array}{l}\text { An informal determination as to how, when, where } \\
\text { and how much resources (financial, people, } \\
\text { knowledge) will be spend on CSR engagement, } \\
\text { together with an assessment of potential benefits now } \\
\text { or in the future }\end{array}$ \\
\hline
\end{tabular}

Figure A7. Labeling for category investment decision. 


\begin{tabular}{|c|c|c|}
\hline Proposition 3: Business Values & BV & \\
\hline BV: Philanthropic & $\mathrm{BV}-\mathrm{PHI}$ & $\begin{array}{l}\text { Primarily focused on entrepreneur's personal social, } \\
\text { and environmental priorities, without any need or } \\
\text { drive for business profits what-so-ever because it's 'a } \\
\text { good thing to do' }\end{array}$ \\
\hline BV: Transforming Ecosystem & BV-TEC & $\begin{array}{l}\text { Primarily focused on creating societal value by } \\
\text { addressing critical social and/or environmental } \\
\text { needs without the need for immediate business profit }\end{array}$ \\
\hline BV: Reengineering Value Chain & BV-RVC & $\begin{array}{l}\text { Primarily focused on improving operational } \\
\text { effectiveness by integration of social, ethical, } \\
\text { environmental and ecological aspects into business } \\
\text { operations and decision-making provided it } \\
\text { contributes to the financial bottom line }\end{array}$ \\
\hline
\end{tabular}

Figure A8. Labeling for category business values.

\begin{tabular}{llll}
\hline Proposition 4: Entrepreneurial Orientation & & EO & \\
\hline EO: Experience & No experience & EO-EXPNO & $\begin{array}{l}\text { No experience with CSR engagement activities in the } \\
\text { past, neither in previous profession or private } \\
\text { Experience with CSR engagement activities in the past, } \\
\text { neither in previous profession or private }\end{array}$ \\
\hline EO:Employment Years & Experienced & EO-EXPYE & No employment years because came straight from \\
& Straight from school & EO-EY-0 & school \\
\hline EO: Age & Employment for $<x>$ years & EO-EY- $<$ nr $>$ & Employed $<>$ years in (several) previous businesses \\
\hline & Age $<25$ & EO-AGE25 & Age younger than 25 years \\
& Age $>25$ but $<35$ & EO-AGE35 & Age between 26 and 35 years \\
& Age $>35$ but $<45$ & EO-AGE45 & Age between 36 and 45 years \\
Age $>45$ but $<60$ & EO-AGE60 & Age between 46 and 60 years \\
Age $>60$ but $<70$ & EO-AGE70 & Age between 61 and 70 years
\end{tabular}

Figure A9. Labeling for category entrepreneurial orientation.

\section{References}

1. Castka, P.; Balzarova, M.A.; Bamber, C.J.; Sharp, J.M. How can SMEs effectively implement the CSR agenda? A UK case study perspective. Corp. Soc. Responsib. Environ. Manag. 2004, 11, 140-149. [CrossRef]

2. Packer, H.; Swartz, W.; Ota, Y.; Bailey, M.J.S. Corporate Social Responsibility (CSR) Practices of the Largest Seafood Suppliers in the Wild Capture Fisheries Sector: From Vision to Action. Sustainability 2019, 11, 2254. [CrossRef]

3. Baden, D.; Harwood, I.A.; Woodward, D.G. The effects of procurement policies on 'downstream' corporate social responsibility activity: Content-analytic insights into the views and actions of SME owner-managers. Int. Small Bus. J. 2011, 29, 259-277. [CrossRef]

4. Deigh, L.; Farquhar, J.; Palazzo, M.; Siano, A. Corporate social responsibility: Engaging the community. Qual. Mark. Res. Int. J. 2016, 19, 225-240. [CrossRef]

5. Elford, A.C.; Daub, C.H. Solutions for SMEs Challenged by CSR: A Multiple Cases Approach in the Food Industry within the DACH-Region. Sustainability 2019, 11, 4758. [CrossRef]

6. Liu, X.; Zhang, C. Corporate governance, social responsibility information disclosure, and enterprise value in China. J. Clean. Prod. 2017, 142, 1075-1084. [CrossRef]

7. Luetkenhorst, W.J.I. Corporate social responsibility and the development agenda. Intereconomics 2004, 39, 157-166. [CrossRef]

8. Perini, F. SMEs and CSR theory: Evidence and implications from an Italian perspective. J. Bus. Ethics 2006, 74, 305-316. [CrossRef]

9. Retolaza, J.L.; Ruiz, M.; San-Jose, L. CSR in business start-ups: An application method for stakeholder engagement. Corp. Soc. Responsib. Environ. Manag. 2009, 16, 324-336. [CrossRef]

10. Vázquez-Carrasco, R.; López-Pérez, M.E. Small \& medium-sized enterprises and Corporate Social Responsibility: A systematic review of the literature. Qual. Quant. 2013, 47, 3205-3218.

11. De Lange, D.E. Start-up sustainability: An insurmountable cost or a life-giving investment? J. Clean. Prod. 2017, 156, 838-854. [CrossRef] 
12. Russo, A.; Tencati, A. Formal vs. informal CSR strategies: Evidence from Italian micro, small, medium-sized, and large firms. J. Bus. Ethics 2009, 85, 339-353. [CrossRef]

13. Voinea, C.L.; van Kranenburg, H. Feeling the squeeze: Nonmarket institutional pressures and firm nonmarket strategies. Manag. Int. Rev. 2018, 58, 705-741. [CrossRef] [PubMed]

14. Van Kranenburg, H.; Voinea, C.L. Nonmarket strategies predictors for foreign firms. Scand. J. Manag. 2017, 33, 82-92. [CrossRef]

15. Xu, S.; Qiao, M.; Che, B.; Tong, P.J.S. Regional Anti-Corruption and CSR Disclosure in a Transition Economy: The Contingent Effects of Ownership and Political Connection. Sustainability 2019, 11, 2499. [CrossRef]

16. Preuss, L.; Perschke, J. Slipstreaming the larger boats: Social responsibility in medium-sized businesses. J. Bus. Ethics 2010, 92, 531-551. [CrossRef]

17. Voinea, C.L.; van Kranenburg, H. Media Influence and Firms Behaviour: A Stakeholder Management Perspective. Int. Bus. Res. 2017, 10, 23-38. [CrossRef]

18. Centobelli, P.; Cerchione, R.; Esposito, E. Knowledge management in startups: Systematic literature review and future research agenda. Sustainability 2017, 9, 361. [CrossRef]

19. Lee, W.; Kim, B. Business Sustainability of Start-Ups Based on Government Support: An Empirical Study of Korean Start-Ups. Sustainability 2019, 11, 4851. [CrossRef]

20. Lee, M.; Park, S.; Lee, K.S. What Are the Features of Successful Medical Device Start-Ups? Evidence from KOREA. Sustainability 2019, 11, 1948. [CrossRef]

21. Mahmood, T.M.A.T.; Al Mamun, A.; Ahmad, G.B.; Ibrahim, M.D. Predicting entrepreneurial intentions and pre-start-up behaviour among Asnaf millennials. Sustainability 2019, 11, 4939. [CrossRef]

22. Teece, D.J. Business Models, Business Strategy and Innovation. Long Range Plan. 2010, 43, 172-194. [CrossRef]

23. Trimi, S.; Bergebal-Mirabent, J. Business model innovation in entrepreneurship. Int. Entrep. Manag. 2012, 8, 449-465. [CrossRef]

24. Yunus, M.; Moingeon, B.; Lehmann-Ortega, L. Building Social Business Models: Lessons from the Grameen Experience. Long Range Plan. 2010, 43, 308-325. [CrossRef]

25. Vázquez-Carrasco, R.; López-Pérez, M.E.; Centeno, E. A qualitative approach to the challenges for women in management: Are they really starting in the 21st century? Qual. Quant. 2012, 46, 1337-1357. [CrossRef]

26. Balewski, B.; Janowski, A. Corporate social responsibility: Does the conception collapse? Економічний часопис-ХХI 2013, 11, 50-53.

27. Barry, B. Expression of Concern Regarding Jensen (2002), "Value Maximization, Stakeholder Theory, and the Corporate Objective Function". Bus. Ethics Q. 2018, 28, 237-239. [CrossRef]

28. Baumann-Pauly, D.; Wickert, C.; Spence, L.J.; Scherer, A.G. Organizing corporate social responsibility in small and large firms: Size matters. J. Bus. Ethics 2013, 115, 693-705. [CrossRef]

29. Amos, G.J.; Baffour Awuah, G. In search of competitiveness through innovation-driven CSR initiatives in Multinational Enterprise subsidiaries in developing countries. J. Dev. Ctry. Stud. 2017, 7, 161-173.

30. Maignan, I.; Ferrell, O.C.; Hult, G.T.M. Corporate citizenship: Cultural antecedents and business benefits. J. Acad. Mark. Sci. 1999, 27, 455-469. [CrossRef]

31. McWilliams, A.; Siegel, D. Corporate social responsibility: A theory of the firm perspective. Acad. Manag. Rev. 2001, 26, 117-127. [CrossRef]

32. Bocken, N.M. Sustainable venture capital-catalyst for sustainable start-up success? J. Clean. Prod. 2015, 108, 647-658. [CrossRef]

33. Rangan, K.; Chase, L.A.; Karim, S. Why Every Company Needs a CSR Strategy and How to Build It; Harvard Business School: Boston, MA, USA, 2012.

34. Crane, A.; Matten, D.; Spence, L. (Eds.) Corporate Social Responsibility: Readings and Cases in a Global Context; Routledge: Abingdon-on-Thames, UK, 2019.

35. Bento, R.F.; Mertins, L.; White, L.F. Ideology and the balanced scorecard: An empirical exploration of the tension between shareholder value maximization and corporate social responsibility. J. Bus. Ethics 2017, 142, 769-789. [CrossRef]

36. Jensen, M.C. Value maximization, stakeholder theory, and the corporate objective function. Bus. Ethics Q. 2002, 14, 235-256. [CrossRef]

37. Carroll, A.B.; Shabana, K.M. The business case for corporate social responsibility: A review of concepts, research and practice. Int. J. Manag. Rev. 2010, 12, 85-105. [CrossRef]

38. Shafer, S.M.; Smith, H.J.; Linder, J.C. The power of business models. Bus. Horiz. 2005, 48, 199-207. [CrossRef] 
39. Lumpkin, G.T.; Dess, G.G. Clarifying the entrepreneurial orientation construct and linking it to performance. Acad. Manag. Rev. 1996, 21, 135-172. [CrossRef]

40. Yin, R.K. The case study as a serious research strategy. Knowledge 1981, 3, 97-114. [CrossRef]

41. Bond, A.; Morrison-Saunders, A.; Pope, J. Sustainability assessment: The state of the art. Impact Assess. Proj. Apprais. 2012, 30, 53-62. [CrossRef]

42. Pope, J.; Annandale, D.; Morrison-Saunders, A. Conceptualising sustainability assessment. Environ. Impact Assess. Rev. 2004, 24, 595-616. [CrossRef]

43. Yin, R. Case Study Research: Design and Methods. Essential Guide to Qualitative Methods in Organizational Research; Sage: Thousand Oaks, CA, USA, 2009; Volume 24.

44. Algozzine, B.; Hancock, D. Doing Case Study Research: A Practical Guide for Beginning Researchers; Teachers College Press: New York, NY, USA, 2016.

45. Baarda, D.B.; Bakker, E.; Fischer, T.; Julsing, M.; Goede, M.P.M.; Peters, V.A.M.; van der Velden, T.M. Basisboek kwalitatief onderzoek: Handleiding voor het opzetten en uitvoeren van kwalitatief onderzoek; Noordhoff Uitgevers: Groningen, The Netherlands, 2005.

46. Boeije, H. Analyseren in Kwalitatief Onderzoek; Boom Lemma Uitgevers: The Hague, The Netherlands, 2014.

47. Lincoln, Y.S.; Guba, E.G. Judging the quality of case study reports. Int. J. Qual. Stud. Educ. 1990, 3, 53-59. [CrossRef]

48. Thomas, D.R. A general inductive approach for analyzing qualitative evaluation data. Am. J. Eval. 2006, 27, 237-246. [CrossRef]

49. Carroll, A.B. The pyramid of corporate social responsibility: Toward the moral management of organizational stakeholders. Bus. Horiz. 1991, 34, 39-48. [CrossRef]

50. Van Marrewijk, M.; Werre, M. Multiple levels of corporate sustainability. J. Bus. Ethics 2003, 44, 107-119. [CrossRef]

51. Burns, P.J.G.; Macmillan, M.P. Entrepreneurship and Small Business: Start-up; Macmillan International Higher Education: London, UK, 2010; Volume 7, p. 51.

52. Fassin, Y.; Van Rossem, A.; Buelens, M. Small-business owner-managers' perceptions of business ethics and CSR-related concepts. J. Bus. Ethics 2011, 98, 425-453. [CrossRef]

53. Berger, E.; Cunningham, P.H.; Drumwright, M.E. Mainstreaming Corporate Social Responsibility: Developing Markets for Virtue. Calif. Manag. Rev. 2007, 49, 132-157. [CrossRef] 